\title{
The Preparation of the Quick-Drying Bitumen Emulsion for the Protection of the Road Surface Asphalt Concrete Layer
}

\author{
VICTORIA S. RYABENKO', ELENA A. CHIGORINA'1, ANATOLY L. RAZINOV'1, \\ YULIA A. UBASKINA ${ }^{1}$ and IVAN D. KOVTUN ${ }^{1,2}$
}

${ }^{1}$ Federal State Unitary Enterprise «State Scientific Research Institute of Chemical Reagents and High

Purity Chemical Substances» (FSUE «IREA»), Bogorodsky val, 3, Moscow, Russia, 107076.

${ }^{2}$ Federal State Budget Educational Institution of Higher Education

«Moscow Technological University», Moscow, Russia.

*Corresponding author E-mail: mousing @ mail.ru

http://dx.doi.org/10.13005/ojc/320634

(Received: October 06, 2016; Accepted: November 27, 2016)

\begin{abstract}
The paper considered getting fast drying bitumen emulsion and study its main operating parameters of the film drying rate and durability of the emulsion. The optimum ratio of the components of the emulsion "binder" - "solvent" - "water".
\end{abstract}

Keywords: Bitumen emulsion, Asphalt, Protection coating, Binder, Petroleum resin, Organic solvent.

\section{INTRODUCTION}

The intensification of traffic and the growing number of a road transport in the Russian Federation lead to a significant increase in load on the transport infrastructure and, in particular, on the asphalt road. Therefore the requirements for strength, safety and durability of the road surface are increasing from year to year.

The outer layer of the road surface, the so-called "wear layer", is the most susceptible to degradation under the influence of external factors. To strengthen the road surface, various techniques and materials were developed which are intended to slow its destruction and preserve it for a long-living repair-free operation of highways.

According to the Guidelines ${ }^{1}$ of the Russian Ministry of Transport, the surface treatment must comply a number of important points to provide transport and operational characteristics of road surfaces. 
Thus, based on the functional purpose, surface treatment should provide:

- Good sealing/covering of the road pavement;

- A rough surface and texture, to ensure a good grip of the car wheels under both dry and wet conditions and the low noise from car traffic for the whole surface lifetime.

- A wear layer that should serve without perceiving deformations and fractures under the impact of traffic loads and environmental factors over a long period of time.

- Low operational costs for the maintenance of the road surface.

This quality can be achieved by treatment of the road surfaces with the impregnating compositions and bituminous emulsions.

The drawbacks of the emulsions used are their instability on storage, long drying time and high consumption of starting materials. In this context, the aim of this work was to obtain cheap, stable and quick-drying bitumen emulsions, useful for treatment of surface protection layer made of road asphalt concrete.

\section{MATERIALS AND METHODS}

To prepare a modified binder, which is the main component of a bitumen emulsion, we have used the viscous road bitumen of the following sorts: BND 60/90 of JSC «Slavneft-YANOS», «JSC Ufa Refinery», JSC «Lukoil», as well as petroleum resin (PR) produced by OPS «Sibplast».

As an organic solvent we have used a hydrocarbon fraction of $140-170^{\circ} \mathrm{C}$ obtained by distillation of commercial Nefras and chemically refined from sulfur and aromatic hydrocarbons. To produce an emulsion, distilled water and a nonionic emulsifier «Metolat-388» were used.

The emulsion was prepared as follows. Bitumen was heated to $90-100^{\circ} \mathrm{C}$ and then placed in a steel vessel equipped with a hot plate, an overhead stirrer and a thermometer.

The stirrer was set in operation, and the rotational speed was set so that the whole mass was stirred vigorously. Then the mixture was heated up to $160^{\circ} \mathrm{C}$. A petroleum resin was added in one portion. Upon reaching the temperature of $180^{\circ} \mathrm{C}$, the time of modification was started to count. After 1 hour, the heating was stopped and the reaction mass was allowed to cool while it was stirred at $120^{\circ} \mathrm{C}$. Then the organic solvent was added, and the mixture was stirred for 15 minutes while maintaining the temperature $90-100^{\circ} \mathrm{C}$.

A hot water $\left(50-70^{\circ} \mathrm{C}\right)$ and an emulsifier were placed in a steel vessel equipped with a hot plate, a dispersant and a thermometer. Dispersant was set at a lowest rotation speed and the mass was heated to $70^{\circ} \mathrm{C}$. Then a mixture of an asphalt binder with an organic solvent warmed to $90-100^{\circ} \mathrm{C}$ were gradually fed in a thin stream to the dispersant to mix with the aqueous phase, while increasing the rotation frequency gradually to $1500 \mathrm{rpm}$. After the required amount of a binder was added, the dispersion process was continued at a rotor speed of $3000 \mathrm{rpm}$ for another $5-10$ minutes to form a homogeneous mass. The prepared emulsion was cooled and poured into a storage container.

Tests with the prepared bitumen emulsion were performed according to standard procedures. The drying time was estimated by the method described in the GOST $19007^{2}$, to the drying level of 3 .

\section{RESULTS AND DISCUSSION}

To improve the properties of a bitumen emulsion, it was recommended to use a modified bitumen as a binder. The modification with polymers may improve the bitumen properties such as cohesion, crack resistance at low temperatures and creep resistance at high temperatures ${ }^{3}$.

In the paper ${ }^{1}$ it is also pointed out, that it is advisable to use polymer-modified bitumen emulsions based on bitumen BND 60/90 or 90/130 to improve the durability of a surface treatment, especially in areas II and III of road-climatic zones (with the average winter temperatures ranging from -10 to $-20^{\circ} \mathrm{C}$ ).

To prepare bitumen emulsions, we have chosen bitumen BND 60/90, as it was found 
previously that bitumen BND 90/130 takes a longer time for its modifying. The petroleum resin has been chosen as the modifier. We have shown previously that the petroleum resin may be successfully used as an effective structure-forming additives to the bitumen of a low viscosity ${ }^{4-7}$. A petroleum resin was added in amounts of $10-15 \%$. The parameters of the modified binders prepared are given in Table 1.
One of the key operational parameters which is important for the use of bitumen emulsion is a drying speed of emulsion films. The drying time of the emulsion films is generally estimated using a modified binder diluent - an organic solvent, and water. Among all of the parameters, the factor of water content is crucial and not only determines the speed of film drying, but also its fire resistance.

Table 1: Parameters modified binder for bituminous emulsion

\begin{tabular}{lccc}
\hline Indicator & $\begin{array}{c}\text { JSC } \\
\text { «Slavneft-YANOS》 }\end{array}$ & $\begin{array}{c}\text { JSC } \\
\text { «Ufa Refinery }\end{array}$ & $\begin{array}{c}\text { JSC } \\
\text { «Lukoil» }\end{array}$ \\
\hline Penetration at $25^{\circ} \mathrm{C} 0,1 \mathrm{~mm}$ & 50 & 49 & 50 \\
Softening temperature, ${ }^{\circ} \mathrm{C}$ & 55 & 56 & 56 \\
Changing the temperature of softening after heating, ${ }^{\circ} \mathrm{C}$ & 5 & 5 & 5 \\
Ductility at $25^{\circ} \mathrm{C}$, sm & 70 & 70 & 70 \\
\hline
\end{tabular}

Table 2: Drying time of bitumen emulsions, depending on water content

\begin{tabular}{|c|c|c|c|c|}
\hline \multicolumn{4}{|c|}{ Emulsion composition, \% } & \multirow{2}{*}{$\begin{array}{l}\text { Drying time of the } \\
\text { film in a thickness } \\
\text { of } 100 \mu \mathrm{m}, \mathrm{min}\end{array}$} \\
\hline Modified binder, \% & $\begin{array}{l}\text { Organic } \\
\text { solvent }\end{array}$ & Emulsifier & Water & \\
\hline 50 & 49 & 1 & 0 & 30 \\
\hline 45 & 44 & 1 & 10 & 60 \\
\hline 40 & 39 & 1 & 20 & 90 \\
\hline 33 & 33 & 1 & 33 & 50 \\
\hline 30 & 29 & 1 & 40 & 80 \\
\hline
\end{tabular}

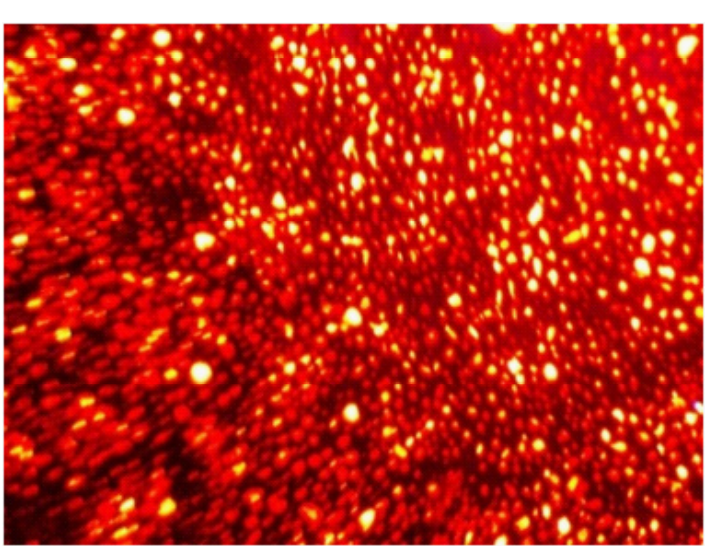

Fig. 1: Bitumen emulsion film containing $50 \%$ of a modified binder (BND 60/90 of JSC «Slavneft-YANOS» and PR), deposited on the slide

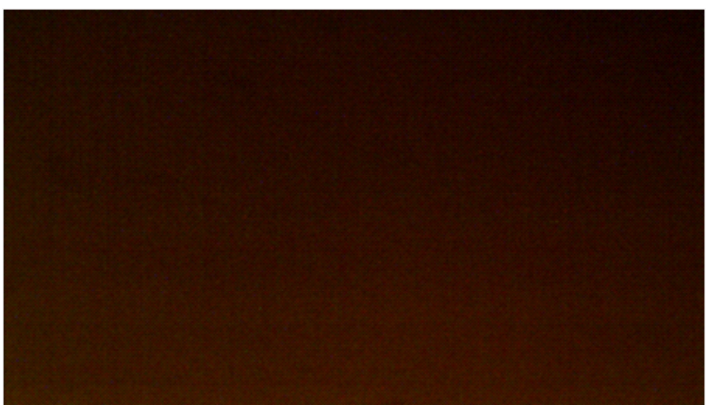

Fig. 2: Bitumen emulsion film containing $40 \%$ of a modified binder (BND $60 / 90$ of JSC «Slavneft-YANOS» and PR) deposited on the slide 
Table 3: Changing the resistance of bitumen emulsions by their composition

\begin{tabular}{lccc}
\hline $\begin{array}{l}\text { Amount of } \\
\text { emulsifier, \% }\end{array}$ & $\begin{array}{c}\text { JSC } \\
\text { «Slavneft-YANOS» }\end{array}$ & $\begin{array}{c}\text { JSC } \\
\text { «Ufa Refinery» }\end{array}$ & $\begin{array}{c}\text { JSC } \\
\text { «Lukoil» }\end{array}$ \\
\hline 0,5 & - & - & - \\
1,0 & + & + & - \\
1,5 & ++ & ++ & + \\
\hline
\end{tabular}

Table 4: Operating data for the protective bitumen emulsions

\begin{tabular}{|c|c|c|}
\hline \multirow[t]{2}{*}{ Operating data } & \multicolumn{2}{|c|}{ Samples of bitumen emulsion } \\
\hline & Sample 1 & Sample 2 \\
\hline $\begin{array}{l}\text { Adhesion coefficient car wheels with asphalt } \\
\text { after an emulsion treatment }\end{array}$ & 0,34 & 0,36 \\
\hline $\begin{array}{l}\text { Change the water saturation after the emulsion } \\
\text { coating and drying treatment, \% }\end{array}$ & 20 & 20 \\
\hline $\begin{array}{l}\text { Uniformity of the application layer of the impregnating } \\
\text { composition on asphalt }\end{array}$ & \multicolumn{2}{|c|}{ No streaks and breaks } \\
\hline Drying time, min & 43 & 50 \\
\hline
\end{tabular}

To determine the water content in the emulsion, which is containing a modified binder on the basis of bitumen BND 60/90 of JSC «SlavneftYANOS» and PR, as well as an organic solvent as a diluent, we have prepared bitumen emulsions containing from 0 to $40 \%$ of water. To study the drying time and coating uniformity, the samples of bitumen emulsions were applied to a special glass plate of $90 \times 120 \times 1.85 \mathrm{~mm}$.

The uniformity of coating by applying was estimated by the spiral applicator rod, 100 microns. The main attention was paid to the uniformity of the layer after application. The thickness of the applied layer was regulated by a universal applicator and was set as $300 \mu \mathrm{m}$ (Table 2).

As we can see from the data given in Table 2 , the optimum amount of water we have to add to obtain a fast drying and nonflammable bitumen emulsion, is $33 \%$.

Also, it was observed that the films formed from those bituminous emulsions containing $40 \%$ or higher of a modified binders are patchy and inhomogeneous. Figure 1 shows a film deposited on the glass, with the content of a modified binder of $50 \%$.

When the content of a modified binder in the emulsion was reduced to $40 \%$, the films become homogeneous (Figure 2).

Thus, for bitumen emulsions, the optimal composition ratio "binder" : "solvent" : "water" with regard to the drying time is $1: 1: 1$. It was also found that the film thickness of such a bituminous emulsion after drying is not exceeded 30 microns. A low film thickness allows to save the consumption of bitumen emulsion applied to the road, while the protective properties towards the asphalt concrete are quite the same.

When choosing an emulsifier, we have evaluated its cost, versatility, availability, affinity to water as well as ability to form stable emulsions. In the paper ${ }^{8}$ it was reported that universal - nonionic emulsifiers could be successfully used to form a 
bitumen emulsion. Therefore, the nonionic emulsifier «Metolat-388" has been selected. According to the chemical composition of the emulsifier, this is a mixture of polyethylene glycols having a strong affinity to water.

Next, we have examined the stability of bitumen emulsions depending on the composition and properties of the starting components; the content of emulsifier in the mixture was varied from 0.5 to $1,5 \%$. To prepare the bituminous emulsions, we used the optimal ratio "binder" : "solvent" : "water" of $1: 1: 1$, as it was shown in Table 2.

Table 3 shows the experimental data on the stability of obtained bituminous emulsions where high stability is denoted as "++", average - as "+" and unstable emulsions noted as "-". The stability was evaluated as the absence of delamination of the emulsion.

Analysis of data in Table 3 shows that $1.5 \%$ of the nonionic emulsifier should be used to prepare a highly stable bitumen emulsions. It should also be noted that the stability of emulsions of bitumen is mainly depends on the starting material properties (in particular, on the parameters of the bitumen).

Two samples of emulsions based on bitumen BND 60/90 produced by JSC «SlavneftYANOS» (sample 1) and JSC «Ufa Refinery» (sample 2) were prepared using the optimal ratio of "binder" - "solvent" - "water" 1: 1: 1 with the emulsifier content of $1,5 \%$.

The resulting bitumen emulsions were applied to the test area of a road surface, and then the treated surfaces were examined. The test results are given in Table 4.
Analysis of data in Table 4 shows that the operating parameters of the protective bitumen emulsion, which was obtained from Bitumen BND $60 / 90$ modified with a petroleum resin, a petroleum solvent and water taken in a ratio of $1: 1: 1$ with addition of $1,5 \%$ of the emulsifier, are meet the requirements of the materials intended to protect road asphalt concrete. The obtained bitumen emulsion provides good sealing properties and a hydrophobic coating. It also retains a rough surface and texture of the asphalt concrete to ensure good adhesion of car wheels under both dry and wet conditions. The wear layer is protected from the effects of weather factors. The protective bitumen emulsion provides low cost maintaining of the surface during the operation.

\section{CONCLUSION}

We have developed the composition and technology of production of nonflammable quickdrying bitumen emulsion to protect road asphalt concrete surface layer. The operating parameters of the bitumen emulsion meet the requirements for materials intended to protect road asphalt concrete specified in standards. The developed composition and technology of production of nonflammable quick-drying bitumen emulsion for protection of road asphalt concrete surface may be recommended for introduction by companies that deal with the production of materials for the road construction sector.

\section{ACKNOWLEDGMENT}

Applied researches are conducted with financial support of the state represented by the Ministry of Education and Science of Russia in under the Subsidy Grant Agreement No 14.579.21.0025 of June 5, 2014. (Unique Identifier for Applied Scientific Researches (project) RFMEFI57914X0025).

\section{REFERENCES}

1. Guidelines for the preparation and use of cationic bitumen emulsions: the disposal of the Ministry of Transport of Russia from 15.09.03 No OS-805-P / JSC "Voronezhavtodor". FSUE “Informavtodor". 2003, 25 (in Russian).
2. GOST 19007 Coating materials method for determining the time and degree of drying. Moscow. 2003, 6. (in Russian)

3. Bitumen emulsion. Technical Bulletin AkzoNobel. 2015, 24. 
4. Chigorina E.A., Razinov A.L., Ubas'kina Y.A. Ryabenko V.S. Orient. J. Chem. 2015, 31(4), 1853-1857.

5. Ubas'kina, Y.A., Chigorina, E.A., Razinov, A.L., Ryabenko, V.S., Kovtun, I.D. Orient. J. Chem. 2016, 32(1), 305-311.

6. Sandu R.A., Glushko A.N., Bulatitckiy K.K., Jdanovich O.A., Pozdnyaeva L.V., RF Patent No. 2516605, Byull. Izobret., 14 (2014).
7. Chigorina E.A., Razinov A.L., Sandu R.A., Jdanovich O.A. Klei. Germetiki.Tekhnologii. 2014, 12, 31-35.

8. Idrisov M.R. Slowly laminating water-bitumen emulsions stabilized compositions based on Proxanol and cation-surfactants. PhD dissertation, FSUE Kazan National Research Technological University, Kazan, 2014, 124 (in Russian) 